\title{
WARISAN PERUBATAN TRADISIONAL DALAM SENI SILAT DI KELANTAN, MALAYSIA
}

\author{
NUR AMALINA MAT RAFI * \\ RAJA ISKANDAR RAJA HALID ** \\ nuramalina.minna@gmail.com*, rajaiskandar@umk.edu.my**
}

\begin{abstract}
Abstrak
Silat merupakan seni mempertahankan diri yang terkenal dalam kalangan masyarakat Melayu dan tersebar luas di Nusantara. Namun, tidak semua dalam kalangan masyarakat mengetahui tentang adanya proses perubatan secara tradisional di dalam persilatan dan kedua-duanya amat memerlukan antara satu sama lain. Dalam erti kata lain, perubatan tradisional dalam seni silat telah bergerak seiring dengan pembelajaran ilmu silat dan berfungsi sebagai ikhtiar untuk menyembuhkan pelbagai jenis penyakit. Aktiviti perubatan tradisional di dalam persilatan ini juga masih lagi diamalkan di Kelantan, yang juga terkenal dengan ritual perubatan melalui seni persembahan seperti Main Puteri dan Mak Yong. Walau bagaimanapun proses perubatan dalam seni silat yang dikaji berbeza dengan Main Puteri dan Mak Yong di mana ia tidak dipertontonkan di hadapan khalayak ramai. Mengungkap secara lebih mendalam mengenai perubatan dalam seni silat, pengkaji akan menerangkan objektif kajian ini iaitu apakah jenis penyakit yang dialami oleh pesakit dan bagaimana proses perubatan dilakukan oleh gurulatih. Di samping itu, pengkaji telah menjalankan kaedah pemerhatian serta pemerhatian secara ikut serta dan menemubual beberapa orang gurulatih seni silat itu sendiri.
\end{abstract}

Kata Kunci: Kelantan, Perubatan Tradisional, Proses Rawatan, Seni Silat 


\title{
TRADITIONAL HEALING HERITAGE IN SENI SILAT IN KELANTAN, MALAYSIA
}

\author{
NUR AMALINA MAT RAFI * \\ RAJA ISKANDAR RAJA HALID ** \\ nuramalina.minna@gmail.com*, rajaiskandar@umk.edu.my**
}

\begin{abstract}
Silat is an art of self-defense that is well known among the Malay community and is widespread throughout the Malay Archipelago. However, the society might not be aware that in silat there is a practice of traditional healing and both need one another. In other words, traditional healing in silat have been moving along with the learning aspect of the martial art and serves as an effort to cure several illnesses suffered by a patient. Silat healing activities are still being practiced in Kelantan, which is known for its traditional healing rituals through the performance of Main Teri and Mak Yong. The healing process in the Seni Silat Pusaka Gayong Malaysia, Kelantan branch is different from Main Teri and Mak Yong and can't be shown to the public. In looking deeper into the healing process in silat, the researcher analyses the objectives of this study which covered the types of illnesses experienced by patients and how healing processes were done by the 'gurulatih'. The research was conducted using the participant-observation method and interviews with a few silat 'gurulatih'
\end{abstract}

Keywords: Kelantan, Traditional Medicine, Treatment Process, Silat Art 


\subsection{Pengenalan Seni Silat}

Seni silat merupakan sebuah warisan budaya masyarakat Melayu yang telah wujud sejak sekian lama namun, asal-usul dan sejarah seni silat agak kabur dan sukar untuk dibuktikan secara ilmiah. Namun, Nisriwani Yahaya dan Syed Zulflida S.M. Noor (2003) menyatakan bahawa seni silat telah bertapak di Kelantan pada zaman pemerintahan Cik Siti Wan Kembang sekitar tahun 1610. Pada ketika itu, baginda menggalakkan gelangganggelanggang silat dibuka oleh mahaguru yang berlatar-belakang agama seperti guru pengajian pondok. Penemuan tinggalan sejarah di Candi Borobodur dan Candi Prambanan di Jawa juga telah membuktikan bahawa seni silat telah wujud di Kepulauan Melayu sekitar abad ke-8 Masihi dan bermula di Kepulauan Riau sehingga berkembang ke Minangkabau, Sumatera dengan dikenali sebagai 'Pencak Silat'. Seterusnya, seni silat berkembang lagi sehingga ke Melaka (Ruzita Alias, 2011). Semasa zaman pemerintahan kerajaan Melaka, ilmu mempertahankan diri ini sangat popular dan dikaitkan dengan kehandalan Hang Tuah dalam menuntut ilmu silat. Di samping itu, para sarjana juga ramai yang mengkaji perihal kepahlawanan Hang Tuah misalnya Haron Daud dan Abdul Rahman Ismail (2014) dalam penulisan mereka menyatakan bahawa Hang Tuah bukan sahaja menguasai ilmu kependekaran dan hulubalang malah beliau juga mempelajari ilmu kebatinan, ilmu mengubati penyakit yang sukar dirawat seperti masalah mandul dan mendalami ilmu-ilmu lain lagi.

Di Malaysia, terdapat sekurang-kurangnya 368 senarai seni silat yang berdaftar dan terdiri daripada pelbagai nama. Antara seni mempertahankan diri yang biasa kita ketahui ialah seni silat Gayong, Cekak Hanafi, Gerak Kuntau, Seni Silat Harimau, Kuntau dan lain-lain (Supyan Hussin, 2017). Namun, pertubuhan seni silat yang paling banyak dan tertua di Malaysia ialah Seni Silat Gayong termasuklah di Kelantan. Perguruan seni silat gayong ini telah diasaskan oleh Allahyarham Dato' Paduka Daeng Meor Abdul Rahman bin Daeng Uda Md. Hashim. Allahyarham merupakan cucu kepada Daeng Kuning atau lebih dikenali dengan nama gelaran Panglima Hitam iaitu salah seorang daripada lima beradik anak Raja Bugis yang telah berhijrah ke Tanah Melayu untuk memulakan kehidupan yang baru

\subsection{Perubatan Tradisional Dalam Seni Silat di Kelantan}

Perubatan tradisional dalam seni silat pada masa ini juga tidak diketahui secara umum dan tidak diamalkan oleh masyarakat berbanding perubatan tradisional lain yang masih lagi mendapat tempat di hati masyarakat Melayu. Bahkan dalam institusi persilatan sendiri juga tidak mementingkan perihal ilmu perubatan tradisional memandangkan terdapat pusat rawatan yang lebih moden untuk merawat penyakit. Hal ini mungkin berlaku ekoran daripada pengamal ilmu mempertahankan diri sendiri telah merahsiakan disiplin seni silat daripada pengetahuan orang ramai dan hanya diperturunkan secara lisan tanpa mementingkan catatan (Ruzita Alias, 2011).

Seperti negeri-negeri lain, negeri Kelantan juga merupakan sebuah negeri yang kaya dengan warisan budaya dan masih lagi berpegang kepada adat resam serta amalan peninggalan nenek moyang seperti dalam kesenian main teri, mak yong, dikir barat, menora dan seni persembahan lain. Begitu juga dengan perubatan tradisional, masyarakat Melayu Kelantan juga masih lagi menggunakan khidmat bomoh, dukun, dan pawang sebagai ikhtiar untuk merawat segala jenis penyakit (Azlina Musa dan Yusmilayati Yunos, 2011). 
Dalam seni persembahan mak yong seperti yang dipetik dalam penulisan Rahimidin Zahari dan Sutung Umar RS (2011) menyatakan bahawa proses perubatan diantara mak yong dan main 'teri' dipercayai mempunyai persamaan iaitu menggunakan alat muzik yang hampir sama. Meskipun kita melihat persembahan mak yong lebih kepada hiburan, namun ianya mempunyai fungsi yang sangat penting untuk menyembuhkan penyakit yang berkaitan dengan spiritual. Di samping itu, kedua-dua seni persembahan tersebut bertujuan untuk memulihkan 'semangat', 'angin' dan 'emosi'. Perkataan 'semangat' bermaksud roh yang terdapat dalam segala makhluk dan dipercayai mempunyai kuasa-kuasa yang tertentu. Kata 'emosi' pula bermaksud, melibatkan perasaan jiwa yang kuat seperti sedih, gembira, takut dan marah. Manakala, perkataan 'angin' pula berkait dengan sifat atau perangai yang tidak menentu atau berubah-ubah tanpa sebab yang nyata (Kamus Dewan Edisi Keempat, 2010).

\subsection{Kajian Literatur}

Melalui kajian literatur, kupasan isu dibincang secara lebih terperinci melalui pelbagai jenis dapatan rujukan sebagai bahan bukti bagi menyokong setiap pembolehubah yang dibentuk, untuk mengumpul seberapa banyak kajian mengenai tajuk perubatan tradisional dalam persilatan, dan semestinya untuk menambahkan ilmu pengetahuan berkaitan perubatan tradisional dari pelbagai sudut. Di samping itu, menjadikan bahan rujukan yang diperoleh untuk memperbaiki kelemahan kajian sendiri. Hal ini demikian kerana, kajian lepas menunjukkan perubatan tradisional dalam kalangan masyarakat Melayu telah banyak dibincangkan sementara maklumat mengenai perubatan tradisional yang diketengahkan melalui persilatan adalah amat sukar diperoleh. Oleh itu, perubatan tradisional dalam persilatan akan dikupas berpandukan maklumat yang diperoleh melalui kajian terdahulu dan dari informasi lain. Antara perkara yang dibincangkan ialah penyakit fizikal dan spiritual, kaedah perubatan tradisional Melayu serta peranan gurulatih dalam memberi rawatan.

\subsection{Jenis Penyakit Yang Dihadapi Oleh Pelatih}

\section{a. Penyakit Fizikal dan Spiritual}

Perkataan fizikal pada dasarnya mengikut Kamus Dewan Edisi Keempat (2005), (Kamus Dewan Edisi Keempat, 2017) ialah berkenaan dengan badan dan jasmani. Manakala perkataan spiritual pula lebih kepada sifat rohani atau jiwa dan bukan bersifat fizikal. Seterusnya, Amran Hassan et al. (2012), pula menjelaskan perihal penyakit fizikal dan spiritual dengan berpandukan sabda Rasulullah S.A.W dan diriwayatkan oleh Al-Bukhari sebagaimana berikut:

"Dan diri kamu mempunyai hak ke atas kamu."

(Sumber: Amran Hassan 2012, ms 52)

Melalui riwayat tersebut dapat disimpulkan bahawa setiap manusia bertanggungjawab untuk menjaga kesihatan diri. Hal ini demikian kerana, setiap anggota tubuh badan manusia mempunyai peranan tersendiri dan bertindak mengikut had yang telah ditetapkan (ibid). Di samping itu, menurut Mat Saad (2008), pula keperluan fizikal merujuk kepada kehendak harian manusia seperti makan, minum, rehat yang cukup, perlindungan dan lain-lain. Manakala, keperluan 
dari segi spiritual pula merujuk kepada pegangan akidah yang kuat dan menjaga amal ibadat kepada Allah S.W.T.

\subsection{Kaedah Perubatan Tradisional Melayu}

\section{a. Perubatan Tradisional: Menggunakan Herba}

Aishah@Eshah Haji Mohamed dan Abd Aziz Bidin (2012) pula telah melakukan kajian keatas tumbuhan dalam upacara perbomohan iaitu menerusi kes 'Main Teri' di Kelantan. Menerusi kajian tersebut, didapati tumbuhan banyak digunakan antaranya ialah padi, sireh, pinang, kunyit dan sebagainya yang bertujuan untuk menyembuhkan penyakit disamping untuk mengetahui kepakaran dan kemampuan bomoh serta menjadikan tumbuhan tersebut sebagai persembahan kepada makhluk ghaib.

Faisal@Ahmad Faisal Abdul Hamid dan Nurul Wahidah Fauzi, (2012) memberi penjelasan bahawa penggunaan herba dalam perubatan telah menjadi amalan kepada setiap masyarakat serta kelompok yang terdiri daripada pelbagai lapisan bangsa malah mewarisi amalan perubatan tersebut. Selain itu, pengaruh perubatan tradisional Melayu juga dikatakan telah diserapi unsur asing. Hal ini demikian kerana, pengaruh tersebut berlaku hasil dari asimilasi para pedagang yang datang ke Tanah Melayu pada kurun ke-14 dengan membawa bersama pelbagai jenis tumbuh-tumbuhan ubatan yang boleh hidup dengan subur.

\section{b. Perubatan Tradisional: Kaedah Urutan}

Teknik urutan merupakan salah satu kaedah rawatan yang juga sering mendapat perhatian masyarakat. Berdasarkan Kamus Dewan Edisi Keempat, Dewan Bahasa dan Pustaka (2013, m.s 1781), perkataan urutan membawa maksud gerakan tangan, mesin dan sebagainya. Urutan tersebut bertujuan untuk melegakan rasa sakit, mengurangkan ketegangan otot serta melancarkan aliran darah dan mempunyai pelbagai kelebihan lagi.

Menerusi kajian 'Amalan urut Melayu tradisional patuh syariah' oleh Rosnani Ripin (2016), beliau menyatakan bahawa amalan urut Melayu tradisional telah menjadi pilihan yang utama apabila kaedah tersebut telah menarik minat pelbagai lapisan masyarakat tanpa mengira bangsa demi mendapatkan rawatan melalui kaedah mengurut dan semestinya pengamal tersebut berbangsa Melayu. Meskipun mengamalkan urutan secara tradisional, pengamal perubatan yang beragama Islam hendaklah menjalankan rawatan berlandaskan Islam. Secara lebih terperinci, isi di dalam artikel ini membincangkan mengenai ciri utama yang perlu ada pada pengamal urut patuh syariah dimana mereka hendaklah beriman dan bertakwa, menjaga hubungan sesama manusia, dan amanah serta bertanggungjawab. Selain itu, di dalamnya juga terkandung etika dan kaedah rawatan urut patuh syariah serta etika pengamal urut yang patuh syariah sama ada sebelum mahupun selepas memberi rawatan dan akhir sekali larangan-larangan untuk pengamal urut patuh syariah. Di samping itu, di dalam penulisannya juga terkandung sifat yang perlu ada pada pesakit, penggunaan ubat dan peralatan yang halal, suci dan selamat serta 
menjamin keselesaan pesakit dengan memberi mengutarakan beberapa prinsip umum Islam terhadap perubatan dan rawatan penyakit.

\section{c. Perubatan Tradisional: Kaedah Islam}

Mengikut sumber bacaan 'Garis Panduan Amalan Pengubatan Islam' oleh Ramli Abd Ghani et al., (2011), telah memberitahu secara lebih jelas mengenai konsep asas dalam pengamalan perubatan Islam iaitu penyembuhan kepada setiap penyakit adalah daripada Allah S.W.T dan ciri-ciri pengamal perubatan islam hendaklah beragama Islam, memahami secara lebih jelas serta mengetahui asasasas ilmu Islam yang merangkumi aspek syariat, berakhlak yang baik dan bertaqwa. Rawatan secara umum merupakan amalan yang yang boleh dilakukan oleh pengamal perubatan dan pesakit itu sendiri iaitu menerusi bacaan ayat AlQuran, berdoa dan berzikir manakala rawatan secara khusus pula termasuklah histeria, santau dan sebagainya yang memerlukan ruang khas semasa sesi rawatan bagi yang melibatkan batasan aurat pesakit. Antara lain yang dijelaskan secara terperinci dalam majalah kesihatan ini ialah piawaian amalan, etika dan profesionalisma sebelum, semasa dan selepas merawat, dan akhir sekali laranganlarangan dalam pengubatan Islam.

Seiring dengan perkembangan agama Islam, kebanyakan masyarakat telah menggunakan amalan ruqyah sepenuhnya secara Islam ekoran keberkesanan dan kuasa penggunaan ayat Al-Quran. Sesetengah masyarakat juga menggunakan amalan ruqyah dan jampi secara tradisional dan islam dimana mereka masih lagi didorong oleh pandangan semesta untuk menangani serta mengubati penyakit sekaligus menghalau semangat jahat. Di samping itu, masyarakat yang beragama Islam juga meyakini bahawa setiap penyakit yang dihadapi sudah pasti akan ada penawarnya (Mohd Qayyuum bin Kamarudin et, al. (2020).

Menurut Nurdeng Deuraseh dan Hayati Lateh (2011), Amalan ruqyah dan jampi juga merupakan satu kaedah yang berkesan dalam perubatan Islam, ianya juga menjadi warisan dan budaya bagi masyarakat Melayu. Hal ini demikian kerana, amalan rukyah didapati telah diamalkan oleh masyarakat Melayu-Muslim semenjak kedatangan Islam ke Nusantara sejak kurun ke-9 lagi manakala jampi pula telah diamalkan oleh masyarakat berasaskan fahaman animise-dinamisme iaitu kepercayaan kepada tenaga dan kekuatan roh, jiwa dan semangat, dan sebagainya semenjak kerajaan Srivijaya sekitar 650-1200 tahun dahulu

\subsection{Gurulatih Seni Silat}

Dalam mempelajari ilmu persilatan, tonggak utama dalam sesebuah pertubuhan adalah seorang gurulatih atau pemimpin. Menurut Muhammad Takari Jilin Syahrial (2015), adat masyarakat Melayu sangat mengutamakan pemimpin, yang disanjung dan dijadikan lambang budaya Islami yang sarat dengan nilai-nilai murni. Masyarakat Melayu menganggap pemimpin sebagai membawa kesejahteraan kepada umat dan bertanggungjawab dalam memberi tunjuk ajar, bersikap adil, amanah, berani mengambil risiko dan sebagainya. 
Bagi seseorang guru silat yang betul-betul berpegang dengan prinsip Islam pula mestilah mengetahui dengan lebih jelas mengenai asas-asas agama. Di samping itu, mereka hendaklah mengerjakan ilmu fardu ain dan fardu kifayah serta menjauhi perkara-perkara yang boleh menyebabkan syirik sama ada melalui perkataan, perbuatan atau niat. Selain itu, seorang guru juga dilarang sama sekali untuk memasukkan unsur-unsur yang bercanggah dengan agama di dalam pembelajaran seni silat contohnya menuntut ilmu kebal (Othman Mustapha, 2008). Dalam organisasi seni silat misalnya seni silat gayong, pemimpin yang tertinggi digelar sebagai mahaguru diikuti gurulatih, jurulatih atau gelaran khalifah muda bagi jurulatih lelaki dan srikandi untuk jurulatih perempuan dan akhir sekali pembantu jurulatih. Kesemua jawatan yang diberikan oleh mahaguru adalah berdasarkan kemahiran seseorang pesilat dalam menguasai latihan dan telah melepasi beberapa ujian keberanian.

Menurut Noresah Baharom (2010), perkataan mahaguru membawa dua maksud iaitu guru yang tertinggi pangkatnya di perguruan tinggi di universiti. Maksud kedua iaitu ketua sesuatu kumpulan silat. Seterusnya, khalifah muda pula bermaksud ketua murid. Dari sudut Islam, perkataan khalifah merujuk kepada pengganti Nabi Muhammad S.A.W dan setiap insan yang diamanahkan oleh Allah untuk mengurus dan mentadbir dunia ini. Manakala, perkataan srikandi bermaksud wanita yang gagah berani dan pahlawan wanita. Perkataan gurulatih pula tiada definisi khusus untuk menerangkan maksudnya. Namun, dalam pertubuhan seni silat, perkataan gurulatih amat gemar digunakan misalnya Majlis Gurulatih Kebangsaan. Mengikut kefahaman pengkaji, perkataan gurulatih mempunyai persamaan dengan maksud jurulatih iaitu merujuk kepada orang yang melatih dan menunjuk ajar pelatih lain secara berulang-ulang untuk menjadikan orang yang diajar itu benar-benar mahir.

\subsection{Metodologi Kajian}

Jenis kajian yang dilakukan adalah berbentuk kualitatif. Hal ini demikian kerana, pengkaji ingin mengetahui secara lebih terperinci mengenai tajuk kajian iaitu dengan cara bersemuka sendiri dengan responden yang dipilih untuk mendapatkan maklumat yang lebih sahih dan tepat. Menurut Hamzah (2010), penyelidikan berbentuk kualitatif merujuk kepada kajian yang dijalankan secara teliti, terperinci dan memerlukan pemerhatian yang lebih jelas. Di samping itu, kajian yang menggunakan pendekatan kualitatif juga tidak memerlukan bilangan responden yang ramai, tetapi pemilihan responden tersebut haruslah bersesuaian. Selain menemubual responden, pengkaji juga telah menjalankan pemerhatian serta pemerhatian secara ikut serta di sekitar kawasan latihan seni silat berlangsung.

\subsection{Sesi Temubual}

Kaedah temubual seperti dalam penulisan Mok Soon Sang (2009) boleh diklasifikasikan kepada empat kategori utama. Antaranya ialah, temu bual berstruktur, temu bual bukan-berstruktur, temu bual bukan-direktif dan temu bual berfokus. Menerusi kajian ini, pengkaji telah menjalankan tiga kaedah temu bual iaitu temu bual berstruktur, bukan-berstruktur dan temu bual melalui telefon. 


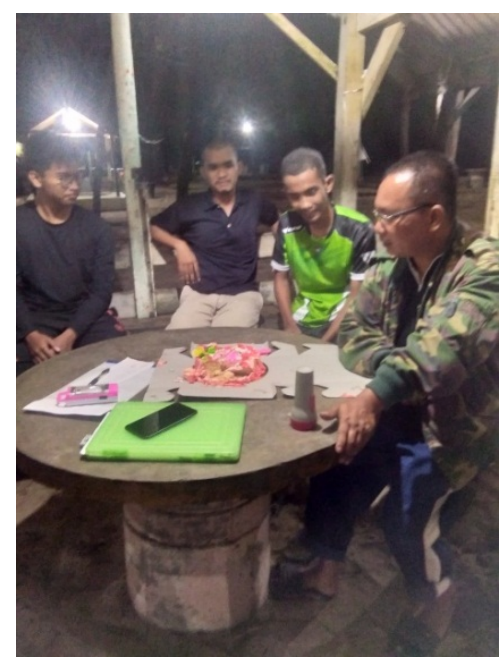

Rajah 1: Gambar menunjukkan sesi temubual yang dijalankan keatas gurulatih seni silat bersama Cikgu Nordin bin Dollah.

(Sumber: Nur Amalina, 2018)

Temu bual berstruktur telah dilakukan dengan cara menyediakan satu set soalan berkaitan dengan peranan gurulatih. Temu bual bukan-berstruktur pula dilakukan secara spontan seperti gambar di dalam Rajah 1 diatas, namun masih lagi mementingkan susunan dan urutan dibawah kawalan pengkaji. Manakala temu bual melalui telefon pula dilakukan dengan cara menghantar khidmat pesanan ringkas kepada responden.

Proses temu bual ini telah dilakukan kepada responden yang dipilih terdiri daripada pengamal perubatan tradisional merangkap jurulatih dalam persilatan di Kota Bharu, Kelantan iaitu Cikgu Nordin, Cikgu Zain dan Encik Kamarulzaman Mohammad, jurulatih Pasukan Briged Gayong UMK iaitu Cikgu Amru, responden yang terdiri daripada pesakit yang menerima rawatan secara tradisional dalam silat iaitu Ain, Hafizul dan Cikgu Lin. Seterusnya, perawat dari Pusat Rawatan Islam iaitu Ustaz Zaki serta tiga orang pembantu beliau. Kesemua mereka mempunyai kepakaran berkaitan dengan selok-belok perubatan tradisional dan semestinya untuk menyokong kaedah rawatan yang digunakan oleh pengamal perubatan dalam seni silat.

\subsection{Kawasan Pemerhatian}

Kawasan pemerhatian telah dilakukan dengan menghadirkan diri di beberapa buah lokasi iaitu di padang Sekolah Menengah Kebangsaan Mulong dimana ianya dijadikan tempat untuk sesi latihan seni silat. Seterusnya, Taman Rekreasi Barokah dan Pantai Sri Melawi dipilih untuk kem perkhemahan serta ujian jati diri. Mengunjungi kediaman gurulatih di Kampung Parit, Pasir Tumboh dan Kampung Seterpa di Bukit Marak, Kelantan. Di samping menghadirkan diri di kawasan pemerhatian, pengkaji telah melakukan kaedah temubual bersama para gurulatih dan pelajar. 


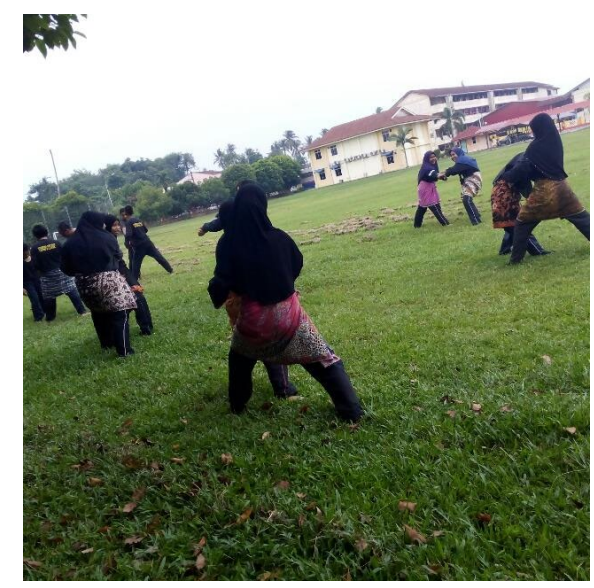

Rajah 2: Gambar menunjukkan kawasan di mana pemerhatian sedang dilakukan di padang Sekolah Menengah Kebangsaan Mulong bagi tujuan kutipan data.

(Sumber: Nur Amalina, 2017)

Gambar di dalam Rajah 2 menunjukkan kawasan pemerhatian pengkaji di padang Sekolah Menengah Kebangsaan Mulong. Kawasan tersebut dijadikan sebagai tapak gelanggang aktiviti seni silat anggaran dari tahun 1999 sehingga tahun 2020 bagi memenuhi aktiviti kokurikulum pelajar.

\subsection{Pemerhatian Ikut Serta}

Melalui kaedah ini, pengkaji telah menyertai sebuah program iaitu Kem Jati Diri dan Ujian Peningkatan Bengkong yang dianjurkan oleh Pertubuhan Seni Silat Pusaka Gayong sejak dari tahun 2008 lagi. Kem tersebut diadakan pada setiap tahun misalnya, pengkaji telah menyertai program yang telah berlangsung selama tiga hari dan dua malam bermula pada 08 September 2017, 26 April 2018 dan 20 Jun 2019. Di samping itu, pengkaji juga telah menghadiri program berkaitan 'Kursus Asas Perubatan dan Pengubatan Islam dan sesi rawatan Islam bersama Darussyifa' Kelantan pada 25 Julai 2019 serta melibatkan diri dalam istiadat 'Mandi Minyak' yang diadakan di Dewan Terbuka Keusahawanan UMK Kampus Taman Bendahara pada 26 November 2019. Pemerhatian secara ikut serta ini dilakukan bagi melihat sendiri bagaimana proses pembelajaran berlangsung. Selain itu, pengkaji juga merupakan seorang ahli yang masih lagi aktif dan telah menghadirkan diri sepanjang latihan bela diri diadakan di padang Sekolah Menengah Kebangsaan Mulong bermula pada tahun 2009 sehingga tahun 2020 . 


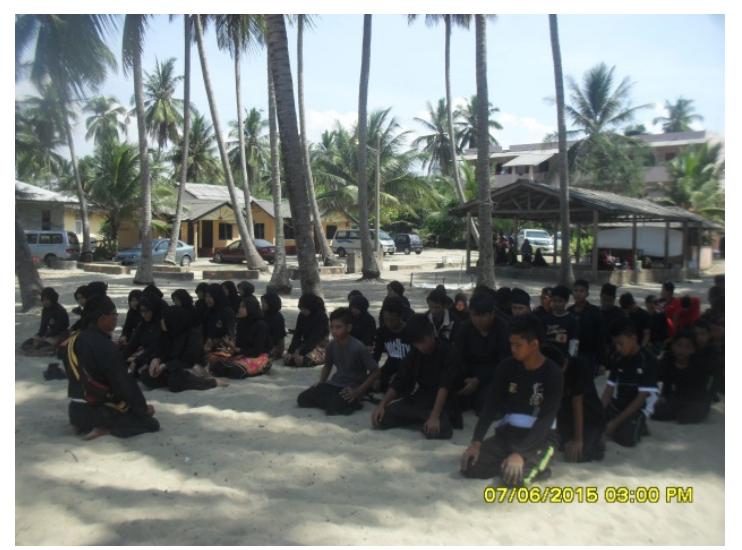

Rajah 3: Gambar menunjukkan aktiviti pembukaan dan penutupan gelanggang (Sumber: Nur Amalina, 2015)

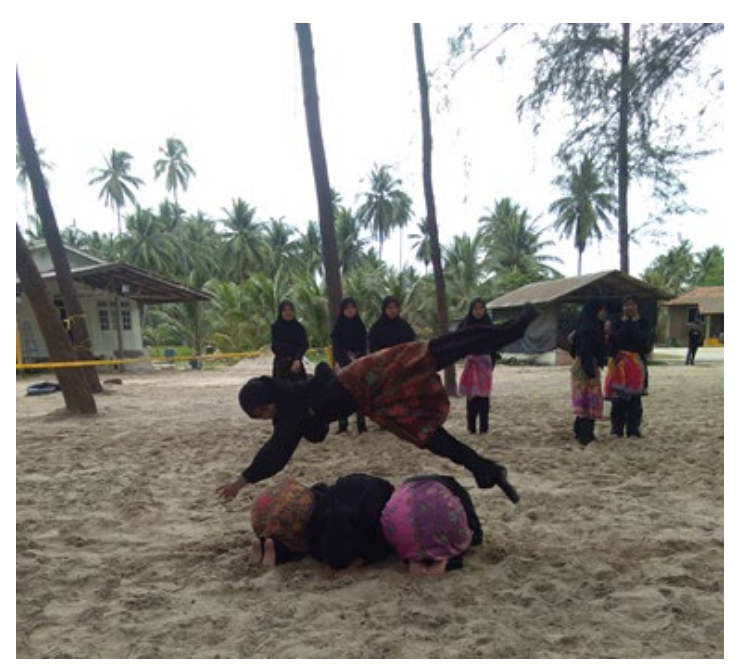

Rajah 4: Gambar menunjukkan ujian keberanian yang dilakukan oleh pelatih wanita

(Sumber: Nur Amalina, 2018)

Gambar-gambar di dalam Rajah 3 dan Rajah 4 menunjukkan antara aktiviti membuka dan menutup gelanggang serta ujian keberanian yang perlu dilalui oleh pesilat sepanjang mempelajari ilmu seni bela diri. Ujian tersebut bukan sahaja menguji sejauhmana keberanian pelajar, malah untuk meyakinkan pelajar bahawa sesukar mana pun ujian yang dihadapi, pelajar haruslah menempuhinya. Melalui ujian-ujian sebeginilah yang bakal menimbulkan kecederaan seperti terseliuh, patah dan penyakit spiritual yang lain. 


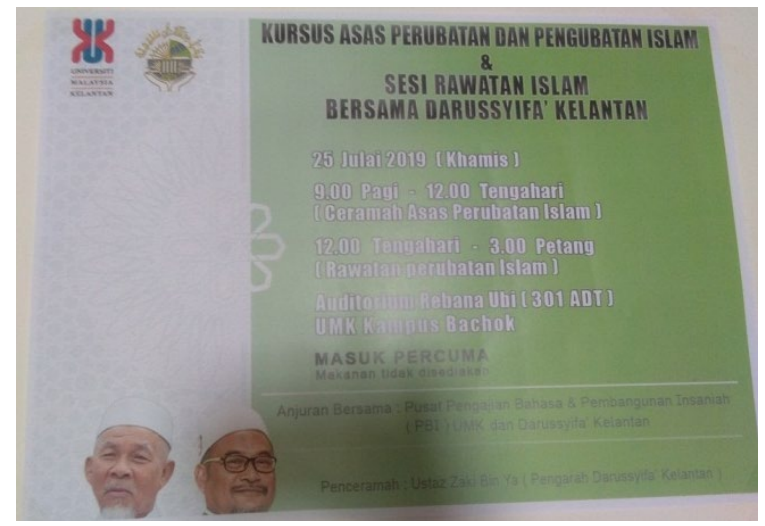

Rajah 5: Poster yang menunjukkan antara program yang disertai oleh pengkaji (Sumber: Nur Amalina, 2019)

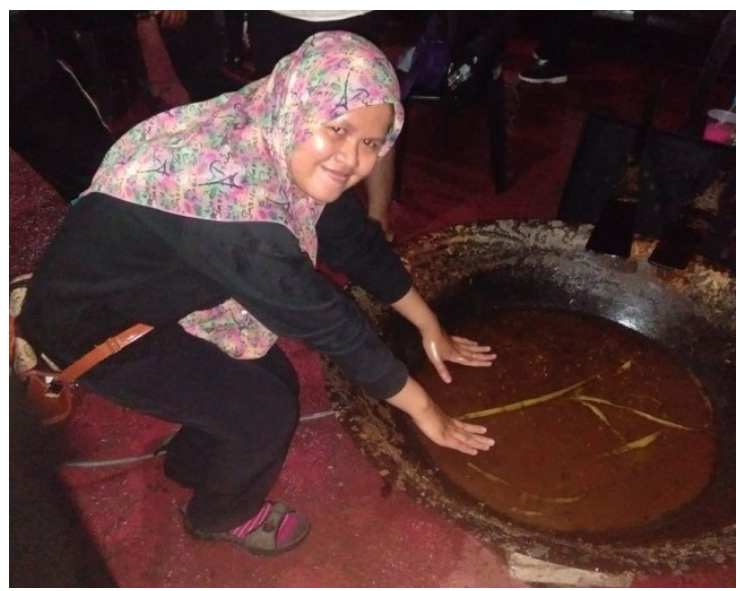

Rajah 6: Gambar menunjukkan penglibatan pengkaji dalam menyertai istiadat 'Mandi Minyak' bersama pasukan Briged Gayong UMK.

(Sumber: Nur Amalina, 2019)

Gambar-gambar di dalam Rajah 5 dan Rajah 6 menunjukkan antara program yang melibatkan pengkaji secara langsung dalam mengumpul maklumat kajian di samping merasai sendiri pengalaman berubat dengan pusat perubatan Islam dan menghadiri istiadat mandi minyak.

\subsection{Dapatan Kajian}

\subsection{Jenis-jenis Penyakit yang Dihadapi Oleh Pelatih Seni Silat}

Dalam mempelajari ilmu persilatan, ketangkasan dan kealpaan semasa menuntut ilmu silat kadangkala membawa kepada kecederaan seperti luka, lebam dan lainlain kerana ianya sudah menjadi suatu kebiasaan atau adat dalam bersilat. Malah, menurut hasil temubual bersama jurulatih seni silat pusaka gayong di Kelantan iaitu Encik Muhammad Zain Muhammad Noor (Cikgu Zain) memberitahu bahawa untuk menjadi seorang yang berani dan sentiasa bersedia dengan apa jua halangan, para pesilat haruslah mempunyai keyakinan yang tinggi dan sanggup menempuhi segala rintangan meskipun berlaku kecederaan semasa berlatih. Menurutnya lagi, beliau 
juga sudah lali dengan kecederaan yang menimpa beliau semasa berlatih misalnya patah jari dan sebagainya.

Antara jenis penyakit fizikal yang biasa menimpa pelatih semasa dalam gelanggang silat ialah terseliuh, patah, luka, tertusuk senjata, pecah kepala dan penyakit yang diluar kebiasaan pelatih seperti paru-paru berair. Bagi penyakit spiritual pula melibatkan gangguan saka, dan histeria. Selain itu, pelatih yang melanggar adat semasa dalam gelanggang juga berpotensi untuk mendapat penyakit misalnya disampuk makhluk halus.

Dalam penulisan oleh Mohd Qayyuum Kamarudin et, al. (2020), menyatakan bahawa pengubatan tradisional Melayu amat menekankan kestabilan empat elemen utama di dalam anggota badan manusia seperti unsur angin, api, air dan tanah. Hal ini demikian bagi mengekalkan tahap kesihatan dan mempunyai peranan yang begitu penting terhadap keseimbangan badan, emosi, fizikal dan mental manusia. Di samping itu, jika berlakunya ketidakstabilan antara keempat-empat elemen tersebut dari segi jasad dan tenaga, berkemungkinan besar akan membawa kepada serangan penyakit fizikal dan spiritual yang pastinya memberi kesan kepada seseorang individu.

Dalam adat gelanggang pula, terdapat beberapa amalan dan pantang-larang yang menjadi kewajipan kepada para pelatih untuk diamalkan. Menurut Sheikh Shamsuddin (2005), ruang sekeliling tempat semasa berlatih silat dipanggil sebagai gelanggang. Sebelum memulakan latihan, pelatih mestilah membuka gelanggang terlebih dahulu dengan cara membaca surah Al-Fatihah satu kali, Al-Ikhlas sebelas kali, selawat keatas Nabi dan para sahabat tiga kali, dan mendoakan kesejahteraan dan keselamatan sepanjang mempelajari ilmu seni silat sehingga selesai.

Pesakit yang berhadapan dengan masalah gangguan makhluk halus mengikut pandangan Haron Din (2011), pengertian sebenar makhluk halus bukan hanya merujuk kepada anasir jahat semata-mata kerana makhluk-makhluk halus tersebut diciptakan oleh Allah SWT dengan jisim yang sangat halus dan tidak dapat dilihat oleh pancaindera manusia. Di samping itu, telah menjadi kebiasaan bagi masyarakat Melayu bahawa jika disebut mengenai makhluk halus, masyarakat sudah pasti akan menggambarkan makhluk yang berupa jin dan hantu.

Berkenaan dengan jenis penyakit sihir pula, Kamus Dewan Edisi Keempat mentakrifkan sihir dari sudut bahasa ialah perbuatan atau kejadian luar biasa yang dilakukan oleh manusia secara tersembunyi atau ghaib yang melibatkan makhluk halus. Menurut pandangan Haron Din (2011) istilah sihir dari sudut syariat pula dilihat daripada pendapat beberapa orang ulama seperti Ibnu Khaldun, Al-Qurtubi, Dr. Abdullah bin Muhammad At-Toyyar, Ibnu Qadamah al-Maqdasi dan lain-lain. Daripada semua pendapat tersebut, Haron Din berpendapat bahawa sihir ialah suatu perbuatan yang jahat dan dilakukan secara tersembunyi bagi bermaksud untuk menganiayai dan menyakiti manusia.

Sesetengah penyakit yang telah menimpa diri pesakit tidak boleh dipertontonkan misalnya penyakit yang berkaitan dengan gangguan makhluk halus. Hal ini kerana, 
mengikut hasil temubual bersama Cikgu Zain, manusia tidak seharusnya berkawan dengan makhluk ghaib seperti jin. Menurut beliau lagi, semasa mengubati pesakit, pelbagai teknik dan helah yang telah digunakan oleh makhluk halus sebelum meninggalkan jasad pesakit dan jika yang menyaksikan rawatan tersebut berkeadaan lemah, kemungkinan besar makhluk tersebut akan berpindah ke badan yang menyaksikan rawatan itu.

\section{a. Penyakit Fizikal: Tertikam dan Tertusuk Senjata}

Perkataan tertusuk ialah benda yang runcing dan tajam untuk mencucuk, mencucuk hingga tembus atau melukakan dengan senjata tajam. Manakala, perkataan tertikam pula bermaksud telah ditikam atau ditikam dengan tidak sengaja (Kamus Pelajar Edisi Kedua, 2019). Kecederaan seperti tertusuk dan tertikam senjata merupakan sebahagian daripada adat dalam latihan jika pelatih alpa dan lalai semasa mempelajari ilmu persenjataan.

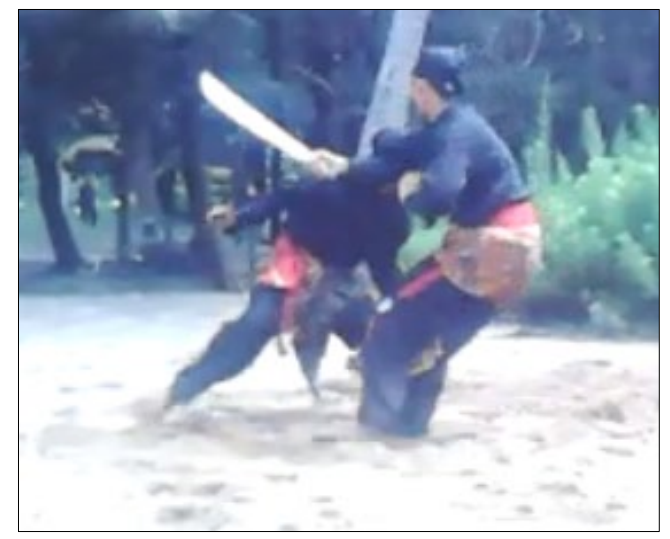

Rajah 7: Situasi berlakunya kecederaan seperti tertusuk senjata (Sumber: Nur Amalina, 2014)

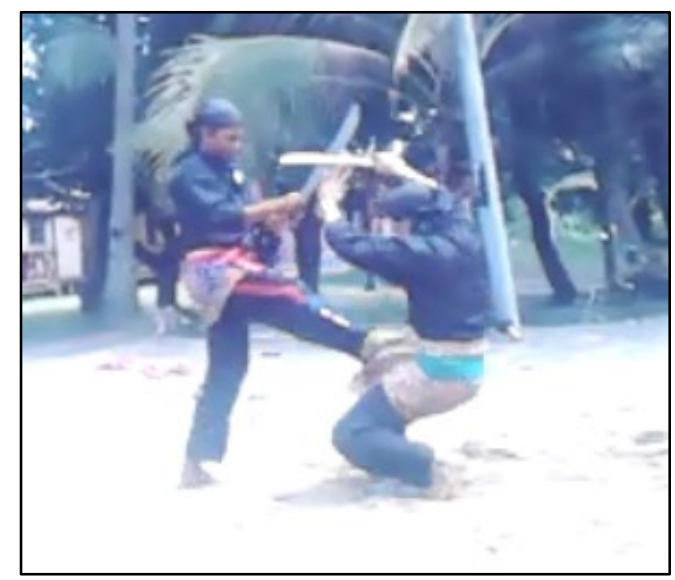

Rajah 8: Situasi berlakunya kecederaan seperti tertusuk senjata (Sumber: Nur Amalina, 2014) 
Gambar-gambar dalam Rajah 7 dan Rajah 8 menunjukkan dua orang pembantu jurulatih yang mahir sedang mempersembahkan seni silat tempur bersenjata. Persembahan tersebut telah berlangsung di kawasan lapang, Pantai Sri Aur, Melawi, Kelantan bersempena dengan majlis penutup kem jati diri dan ujian peningkatan bengkong anjuran Pertubuhan Seni Silat Pusaka Gayong Malaysia pada tahun 2014. Kedua-dua pembantu jurulatih tersebut merupakan diantara mereka yang mahir dalam teknik bela diri menggunakan senjata. Senjata yang digunakan adalah parang, pisau dan kerambit.

Pada tahun 2015, rakyat Malaysia pernah digemparkan dengan berita kematian seorang pelatih Seni Silat Gayong Serantau yang maut tertikam senjata iaitu keris semasa sedang melakukan persembahan. Mungkin disebabkan kecederaan sebegini, kebanyakan sekolah yang menganjurkan seni silat sebagai aktiviti kokurikulum tidak lagi membenarkan pelajar seni silat untuk mempelajari ilmu seni senjata. Selain itu, Persatuan Seni Silat Kebangsaan Malaysia (PESAKA) juga telah mengeluarkan pekeliling baharu dengan mengehadkan pembelajaran senjata hanya dibenarkan untuk pelatih yang berumur 18 tahun keatas sahaja (Malaysiakini, 2015).

\section{b. Penyakit Luar Kebiasaan Pelatih}

Dalam sesi temuramah yang dijalankan juga, terdapat seorang pelatih perempuan yang menghidap penyakit di luar kebiasaan pelatih. Beliau merupakan seorang pesakit jantung atau paru-paru berair sejak dari kecil dan telah dirawat secara batin oleh Cikgu Zain. Memandangkan beliau amat meminati ilmu mempertahankan diri, jadi beliau berkeras untuk mempelajarinya walaupun tahu akan implikasi yang bakal terjadi. Maklumat mengenai beliau tidak dapat didokumentasi secara penuh ekoran daripada pelbagai masalah yang menimpa beliau. Namun, pengkaji hanya dapat menceritakan serba sedikit mengenai proses perubatan yang dilakukan keatas diri beliau pada tahun 2017 yang lepas. Pada ketika itu, pengkaji telah melihat dengan jelas proses tersebut berlangsung disamping menemu ramah beliau.

Hasil daripada temu ramah bersama pelatih, beliau menyatakan bahawa beliau sememangnya merasa amat takut untuk berkongsi perihal penyakit yang dihidapinya. Tambahan pula, setelah ditanya mengapa beliau enggan menceritakan pengalaman berubat secara batin, pesakit akhirnya memberitahu bahawa beliau telah membuat temujanji dengan pihak hospital berkenaan kesihatan dirinya. Jadi, beliau ingin mendapatkan keputusan kesihatan diri daripada pihak hospital terlebih dahulu sebelum membuat keputusan untuk berubat secara tradisional.

\section{c. Penyakit Spiritual: Histeria}

Konsep histeria menurut Intan Farhana Saparudin et, al. (2014) dari sudut dunia perubatan ialah dikelaskan sebagai penyakit mental dan psikiatri. Bagi masyarakat Melayu pula, mereka menganggap penyakit histeria adalah tanda seseorang telah dirasuk hantu atau diganggu makhluk halus. Tambah beliau lagi, persepsi ini muncul ekoran daripada sebelum kedatangan Islam, masyarakat Melayu lebih mempercayai konsep animisme. Sehingga kini, walaupun masyarakat Melayu 
beragama Islam, namun kepercayaan terhadap perkara tahyul masih lagi menebal.

Sepanjang pengkaji menyertai perkhemahan seni silat yang berlangsung sepanjang tahun 2007 sehingga 2019, hanya beberapa kali sahaja gejala histeria berlaku. Namun, gangguan histeria tersebut tidak terlalu kuat dan masih lagi terkawal. Mengikut pengamatan pengkaji, gangguan tersebut akan berlaku sekiranya pelatih tidak menjaga kebersihan diri, bertutur kata yang tidak sopan dan melanggar arahan gurulatih. Mengikut penceritaan daripada Cikgu Lin, pada tahun 2016 yang lepas terdapat satu gangguan histeria yang berlaku terhadap seorang pelatih perempuan. Pada masa itu, pengkaji tidak dapat menghadiri sesi perkhemahan ekoran daripada kekangan masa. Menurut Cikgu Lin, pelatih perempuan tersebut secara tidak sengaja bermain di luar kawasan tapak khemah walaupun telah diberitahu supaya tidak melanggar kawasan tersebut. Pelanggaran arahan tersebut akhirnya menyebabkan pelatih tersebut melihat kelibat makhluk halus dan meracau.

\subsection{Kaedah Rawatan}

\section{a. Penyakit Fizikal: Menggunakan Herba}

Dalam mempelajari ilmu Seni Silat Pusaka Gayong, para pelatih diharuskan untuk mengikuti adat istiadat mandi minyak. Upacara mandi minyak tersebut pula dilakukan dengan cara menyediakan sebiji kelapa bagi setiap orang pelatih. Buah kelapa tersebut akan dikopek, isinya akan dikukur dan diperah untuk mengambil santan seperti yang ditunjukkan dalam Rajah 9. Santan tersebut pula akan dimasak di dalam kawah yang besar selama beberapa jam sehingga menjadi minyak.

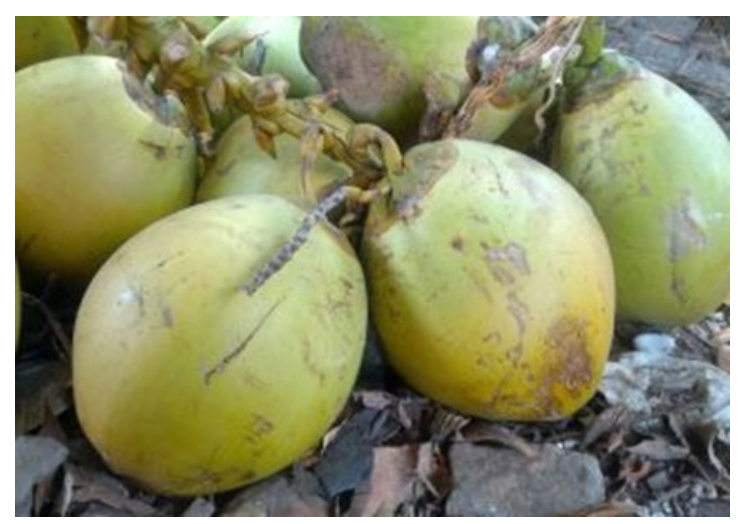

Rajah 9: Gambar menunjukkan buah kelapa yang diguna dalam rawatan.

(Sumber: Ensiklopedia Jurnal Bumi, 2018)

Berkenalan secara lebih jelas mengenai buah kelapa, nama saintifik bagi buah tersebut ialah 'cocos nucifera' atau dalam Bahasa Inggeris lebih dikenali dengan 'coconut'. Menurut Mohd Hilmi Abdullah (2014), dalam penulisan beliau menyatakan bahawa buah kelapa bersifat paras pada permukaan tahap yang kedua dan kering pada tahap yang pertama. Tambah beliau, buah kelapa mempunyai pelbagai kegunaan misalnya, isi kelapa tua sangat baik dimakan untuk membunuh dan mengeluarkan cacing di dalam badan manusia. Selain itu, air kelapa pula sangat sesuai diminum untuk melegakan mabuk dan merawat sihir. 
Semasa menjalankan sesi temubual bersama beberapa orang responden yang terdiri daripada gurulatih seni silat merangkap pengamal perubatan iaitu Encik Kamarulzaman Mohammad atau lebih dikenali sebagai Pak Kamal memberitahu bahawa minyak kelapa amat baik untuk merawat kecederaan seperti patah. Menurut Pak Kamal, minyak tersebut akan dicampur dengan beberapa bahan asli yang lain seperti dibawah:

Bahan-bahan yang diperlukan untuk merawat patah ialah:
a) Daun jarak,
b) Minyak kelapa,
c) Kunyit,
d) Beras,
e) Telur ayam kampung.

\section{Cara penggunaan:}

a) Campurkan kesemua bahan diatas

b) Tumbuk atau giling bahan-bahan tersebut di atas tapak pasu.

c) Setelah sebati, tampalkan adunan tersebut di tempat kecederaan / patah.

d) Seterusnya balut kecederaan tersebut.

\section{b. Rawatan Penyakit Luar Kebiasaan pelatih: 'Scan' atau Bedah Batin}

Cikgu Zain meminta izin untuk melihat sejauh mana penyakit yang dialami oleh Ain dengan cara 'scan' dan bedah secara batin. Pada mulanya Ain kelihatan agak raguragu untuk membenarkan dirinya dirawat, namun Cikgu Zain meyakinkan beliau bahawa tujuannya hanya ingin membantu dan merawat dengan kepakaran yang ada. Pada masa yang sama, pengkaji juga melihat sendiri proses 'scanning' yang dilakukan oleh Cikgu Zain dan mendapati bahawa gurulatih tersebut membaca beberapa potong ayat al-Quran dan berkelakuan seperti membedah bahagian belakang pesakit. Walaupun kelihatan agak pelik, namun Cikgu Zain memberitahu bahawa beliau hanya menggunakan seratus peratus ayat al-Quran dan menegaskan bahawa tidak menggunakan sebarang kaedah yang boleh menyesatkan pegangan beliau sebagai seorang yang taat kepada perintah Allah S.W.T

Berkenaan dengan status rawatan bedah batin pula, pengkaji telah menelaah beberapa penulisan para ilmuwan dan meminta pendapat daripada Ustaz Zaki semasa sesi ceramah berkaitan perubatan Islam berlangsung. Menurut Ustaz Zaki, setelah perbincangan antara para ulama' dilakukan mengenai kaedah bedah batin, mereka sebulat suara menyatakan bahawa kaedah tersebut adalah tidak relevan. Hal ini demikian kerana, kaedah bedah batin dilakukan dengan cara menyihir pandangan pesakit dan orang ramai daripada melihat bagaimana rawatan tersebut dilakukan. Tambah beliau, hanya pengamal kaedah bedah batin sahaja yang tahu dan ianya boleh menyebabkan pesakit akan meragui serta kurang percaya. 


\section{c. Penyakit Spiritual: Ruqyah}

Menurut Phayilah Yama et. al., (2017), perkataan 'Ruqyah' merupakan bacaan ayat-ayat suci Al-Quran yang tertentu dan dikatakan mampu memberi kesan penyembuhan terhadap pelbagai jenis penyakit. Selain surah-surah lazim, penulis juga menyatakan bahawa teks yang dibacakan oleh pengamal perubatan terdiri daripada dua jenis iaitu ayat-ayat Al-Quran dan doa-doa yang bersumberkan daripada Nabi Muhammad S.A.W. Berikut merupakan sabda Rasulullah S.A.W dimana memberi petunjuk dan panduan kepada manusia dalam mencari penawar bagi menyembuhkan segala penyakit

"Ruqyah itu adalah bacaan-bacaan ayat al-Quran, doa-doa Rasulullah, ma'thurat apabila dibacakan dapat menyembuhkan penyakit."(Phayilah Yama et. Al., 2017)

Menurut Muhammad Faiz Mohd Nazri (2018), di dalam penulisannya pula, beliau menyatakan bahawa terdapat dua jenis Ruqyah dalam Islam. Ruqyah tersebut disebut 'Ruqyah Syikiyyah' iaitu ruqyah yang mengandungi unsur syirik, menggunakan khidmat makhluk halus atau syaitan, dan yang pastinya tidak dibenarkan sama sekali dalam Islam. Hal ini demikian kerana, Ruqyah Syikiyyah boleh menyebabkan manusia tersasar jauh daripada Allah S.W.T. Satu jenis Ruqyah lagi ialah yang dibenarkan oleh Islam dan dikenali dengan 'Ruqyah Syar'iyyah'. Kandungan Ruqyah Syar'iyyah biasanya terdiri daripada ayat-ayat alQuran, memohon kesembuhan hanya daripada Allah S.W.T dan tidak sesekali akan terlibat dengan aktiviti paranormal, spiritual dan sebagainya yang boleh memesongkan akidah. Berikut merupakan ayat-ayat al-Quran yang dijadikan sebagai Ruqyah dalam menyembuhkan penyakit:
a) Al-Fatihah
b) Al-Baqarah ayat 1-5
c) Al-Baqarah ayat 102
d) Al-Baqarah ayat 255 (Ayatul Qursi)
e) Al-Baqarah ayat 284-286
f) Ali Imran ayat 18-19
g) Al-'Araf ayat $54-56$
h) Al-'Araf ayat 117-122
i) Yunus ayat $81-82$
j) Toha ayat 69
k) Al-Mukminun ayat 115-118
I) As-Soffat ayat 1-10
m) Al-Ahqaf ayat 29-32
n) Ar-Rahman ayat 33-36
o) Al-Hasyr ayat 21-24
p) Al-Jinn ayat 1-9
q) Al-Ikhlas ayat 1-4
r) Al-Falaq ayat 1-5
s) An-Naas ayat 1-6 
Sepanjang melakukan kajian, pengkaji mendapati responden atau pengamal rawatan yang ditemubual masing-masing menggunakan kaedah ruqyah, melazimi rawatan dengan beberapa doa pilihan serta menggunakan selawat syifa untuk merawat penyakit dan diajarkan zikir harian sebagai pendinding untuk pesakit. Terdapat 18 buah petikan ayat-ayat Al-Quran yang menjadi amalan bagi setiap pengamal perubatan untuk mengubati penyakit spiritual. Antara potongan surahsurah yang digunakan ialah surah Al-Fatihah, Al-Baqarah, Ali Imran, Al-A'araf, Yunus, Toha, Al-Mukminun, As-Soffat, Al-Ahqaf, Ar-Rahman, Al-Hasyr, Al-Jin, AlIkhlas, Al-Falaq dan An-Nas. Doa-doa yang menjadi amalan zikir harian pula terdiri daripada doa sebelum tidur, selawat syifa, dan beberapa doa lain lagi.

\subsection{Peranan Gurulatih Dalam Merawat Pesakit}

Menurut hasil temubual bersama gurulatih seni silat iaitu Encik Nordin bin Dollah atau dikenali dengan gelaran Cikgu Din, tidak semua gurulatih yang pandai dalam selok-belok penggunaan ilmu pengubatan termasuklah diri beliau sendiri. Tambahnya, beliau hanya tahu menggunakan ilmu perubatan herba untuk merawat penyakit jasmani seperti luka-luka kecil. Menyedari bahawa terdapat banyak sebab mengapa gurulatih perlu pandai mengubati penyakit, beliau mula belajar tentang perubatan tradisional dengan berpandukan ayat suci al-Quran.

Ditanya lebih lanjut mengenai bagaimana seseorang gurulatih mengetahui perihal ilmu perubatan, Cikgu Zain memberitahu bahawa beliau disuruh oleh mantan guru beliau supaya menuntut ilmu berubat dan ilmu batin. Tambah beliau, semasa zaman bergelar pelatih seni silat, beliau sentiasa mengikut kemana sahaja gurulatih beliau pergi. Menurutnya, beliau sangat takut untuk mempelajari ilmu berubat apatah lagi bila meibatkan penyakit gangguan makhluk halus. Namun, berkat ajaran daripada gurulatih dan dengan izin Allah beliau cekalkan hati sehinggalah beliau berjaya merawat pelbagai jenis penyakit.

Berkenaan dengan peranan gurulatih dalam merawat penyakit, setiap orang gurulatih menggunakan pendekatan rawatan yang berbeza. Hal ini kerana, ada gurulatih yang menggunakan ayat al-Quran, menggunakan kain putih, kain kuning, pacak keris di hujung kaki dan sebagainya. Mengambil contoh rawatan penyakit menggunakan keris, Shahrun Yub (1967) dan Azlina Musa (2011) menyatakan bahwa keris merupakan alat senjata yang digunakan oleh masyarakat Melayu yang telah digunakan lebih daripada enam ratus tahun dahulu. Masyarakat Melayu Kelantan juga dikatakan akan menyimpan alat senjata seperti keris untuk kegunaan harian atau sebagai koleksi peribadi.

\subsection{Analisis dan Perbincangan}

Hasil daripada pemerhatian dan kajian mengenai perubatan tradisional dalam Seni Silat Pusaka Gayong di Kota Bharu, Kelantan mendapati bahawa sememangnya wujud aktiviti merawat penyakit secara tradisional khususnya di dalam seni silat. Dalam hal ini, gurulatih seni silat yang mempunyai kemahiran berubat akan bertindak sebagai pengamal perubatan dan memberikan rawatan kepada setiap orang pelatih yang diserang penyakit atau mengalami kecederaan. Penyakit-penyakit ini terdiri daripada penyakit berbentuk fizikal dan 
spiritual. Selain itu terdapat juga beberapa orang pelatih seni silat yang mengalami penyakit yang di luar kebiasaan pelatih seperti penyakit paru-paru berair namun tetap mendapatkan rawatan daripada gurulatih seni silat.

Daripada pemerhatian yang dilakukan juga mendapati ada perbezaan yang amat ketara diantara penyakit fizikal dan penyakit spiritual. Penyakit fizikal yang dihadapi oleh pelatih biasanya akan kelihatan dengan lebih jelas di badan pesakit misalnya kecederaan sendi dan otot, patah pada bahagian anggota badan, tertusuk atau tertikam senjata, dan luka. Manakala bagi penyakit spiritual pula biasanya agak sukar untuk dikenalpasti kerana ianya lebih melibatkan bahagian dalaman badan pesakit dan hanya akan diketahui oleh orang di sekeliling apabila pesakit tidak menyedarkan diri, berkelakuan ganjil, mengamuk dan sebagainya. Antara penyakit spiritual yang sering dihadapi oleh pelatih seperti terkena gangguan makhluk halus akibat daripada keturunan keluarga, sihir, gangguan saka, histeria, dan pengamalan ilmu yang salah.

Dalam merawat penyakit fizikal seperti yang diterangkan sebelum ini, proses rawatannya lebih bergantung kepada penggunaan herba, air dan tumbuh-tumbuhan semulajadi yang terdapat di sekeliling kita. Antara herba dan tanaman yang digunakan ialah buah kelapa dan lain-lain. Sebenarnya terdapat banyak lagi herba dan tanaman yang digunakan oleh masyarakat Melayu pada zaman dahulu namun pengkaji hanya menyenaraikan beberapa jenis herba sahaja yang sering dijadikan bahan rawatan oleh pengamal.

Menurut Faisal@Ahmad Faisal Abdul Hamid dan Nurul Wahidah Fauzi (2012), dengan memetik beberapa penulisan daripada para sejarawan terdahulu mengenai perubatan tradisional berasaskan herba misalnya kajian H.C Ong (1994). Melalui penulisan H.C Ong (1994), terdapat sebanyak 54 jenis herba yang digunakan oleh penduduk untuk merawat pelbagai jenis penyakit yang ringan. Selain itu, dalam penulisan oleh Ibrahim Jantan (2006), pula mengulas secara lebih terperinci mengenai nilai produk herba dalam beberapa kategori. Kategori tersebut dikelaskan mengikut aspek kualiti, keselamatan dan efikasi (kepercayaan) agen penyembuh penyakit.

Manakala bagi merawat penyakit spiritual pula, pengamal perubatan Islam merangkap gurulatih seni silat akan menggunakan seratus peratus bacaan ayat suci al-Quran misalnya merawat dengan kaedah Ruqyah. Menurut Khairul Ghazali (2014) dalam penulisannya menyatakan bahawa untuk memastikan rawatan secara Ruqyah adalah bersesuaian dengan syarie, para pengamal hendaklah menitikberatkan beberapa perkara. Perkara yang perlu dilaksanakan adalah seperti di bawah:

1. Membaca ayat-ayat al-Quran dan berpandukan hadis Rasulullah

2. Doa yang dibaca mestilah jelas dan terang

3. Tidak meminta tolong dari makhluk lain selain Allah S.W.T.

4. Tidak menggunakan barang-barang yang menimbulkan syirik

Sepanjang melakukan pemerhatian secara ikut serta dan temubual bersama informan, kesemua mereka mengatakan bahawa kaedah yang paling berkesan dalam merawat pesakit yang terkena gangguan adalah dengan cara melakukan Ruqyah. Bertepatan dengan penulisan oleh Khairul Ghazali (2014), pengkaji melihat sendiri bagaimana persiapan yang dilakukan oleh pengamal perubatan sebelum melakukan rawatan keatas 
pesakit. Antara persiapan yang dilakukan oleh pengamal ialah meminta izin untuk merawat, menyediakan barang-barang keperluan pesakit seperti air dan bekas serta menjaga aib pesakit. Semasa merawat pula, pengkaji mendapati ayat-ayat yang dibaca oleh pengamal adalah seratus peratus ayat al-Quran dan ianya dibaca dengan penuh semangat sehingga dapat mengeluarkan makhluk halus yang mengganggu.

Selain itu, hasil penelitian pengkaji sepanjang sesi temubual juga mendapati bahawa setiap informan mempunyai had yang tertentu sahaja dalam merawat penyakit fizikal. Misalnya, semasa menemubual Cikgu Din memberitahu hanya boleh mengurut bahagian badan yang sakit seperti terseliuh, mengubati luka dan berkongsi beberapa petua mengenai penggunaan herba dalam merawat diri sendiri misalnya merawat penyakit paru-paru berair.

Bagi pelatih yang mengalami kecederaan fizikal atau spiritual juga, mereka dilihat sangat positif dalam menghadapi penyakit. Hal ini amat bersesuaian dengan penulisan oleh pengkaji lain iaitu $\mathrm{H}$. Zulkifli, (2016) yang menyatakan bahawa setiap penyakit dan kecederaan yang diturunkan adalah daripada Allah S.W.T dan daripada Dia jugalah yang menurunkan penawar bagi kegunaan hambanya tanpa mengira agama. Untuk menguatkan lagi kenyataan tersebut, terdapat beberapa potong hadis yang boleh dijadikan sandaran misalnya Rasulullah S.A.W pernah bersabda dalam sebuah hadis iaitu daripada Abu Hurarah R.A yang bermaksud:

"Tidaklah Allah menurunkan penyakit kecuali Dia turunkan untuk penyakit itu ubatnya." (Hadis riwayat Bukhari: Kitab al-Tibb, ms.113)

Sementara itu, Jabir Radiallahuanhu juga ada meriwayatkan sebuah hadis yang berkaitan dengan penyakit dan penawarnya menerusi hadis Rasululullah S.A.W yang bermaksud:

"Setiap penyakit ada ubatnya. Maka bila ubat itu bersesuaian penyakit akan sembuh dengan izin Allah S.W.T." (Hadis riwayat Imam Muslim: Kitab al-Salaam)

Sepanjang melakukan penelitian terhadap peranan gurulatih pula, pengkaji mendapati bahawa gurulatih memainkan tanggungjawab yang begitu besar dalam menguruskan gelanggang seni silat. Hal ini demikian kerana, gurulatih bukan sekadar berperanan untuk mencurahkan ilmu seni mempertahankan diri malah mereka perlu menjadi seorang 'bapa' dan 'ibu', tempat rujukan dan menjadi tulang belakang kepada anak-anak didik. Di samping itu, perkara yang paling utama dan perlu diambil perhatian oleh gurulatih ialah memastikan kesihatan para pelatih sentiasa berada dalam keadaan baik dan bersegera memberikan rawatan jika berlakunya kecemasan. Oleh itu, telah menjadi suatu keharusan bagi para gurulatih untuk mengetahui, mempelajari ilmu rawatan dan berkemahiran dalam selok-belok dunia pengubatan.

Seterusnya, pada pengamatan pengkaji juga mendapati bahawa para pelatih menumpahkan sepenuh kepercayaan kepada gurulatih mereka. Menurut gurulatih yang ditemubual, mereka mengakui bahawa pada mulanya amat sukar untuk menarik kepercayaan pelatih perihal perubatan tradisional. Hal ini kerana kebanyakan pelatih terdiri daripada golongan remaja yang kurang pengetahuan mengenai perubatan tradisional dan jarang membaca al-Quran. Namun apabila rawatan yang dilakukan berkesan, para pelatih masing-masing percaya bahawa diri mereka akan selamat selagi berada di bawah 
pengawasan gurulatih. Pengkaji juga melihat setiap informan suka memberikan motivasi, nasihat dan kata-kata semangat untuk pesakit mereka supaya menguatkan ketahanan mental dan fizikal sepanjang menempuhi ujian kesakitan serta menganggap bahawa ujian tersebut menandakan Allah S.W.T sayang akan hambaNya.

Dalam satu penulisan oleh $\mathrm{H}$. Zulkiflee (2016) menyatakan bahawa, pengaruh rohani yang kuat akan memberi kesan yang baik kepada kesihatan fizikal dan begitu juga berlaku jika sebaliknya. Tambah beliau, amalan seperti sentiasa bersyukur, redha, tawakkal dan positif akan menyihatkan jasmani seseorang. Begitu juga dengan amalan bacaan ayat al-Quran yang berfungsi sebagai penawar bagi penyakit fizikal dan spiritual namun menurutnya tidak semua orang yang diberikan hidayah untuk mengubati dengan al-Quran. Beliau menjelaskan bahawa jika rawatan tersebut dilakukan dengan penuh keikhlasan dan pengaharapan yang penuh terhadap kekuasaan Allah S.W.T dalam menyembuhkan penyakit maka dengan izin Allah penyakit tersebut akan sembuh.

Sepanjang penglibatan dalam seni silat, pengkaji merupakan salah seorang ahli yang masih lagi aktif dalam menuntut ilmu mempertahankan diri sejak dari tahun 2007. Sepanjang berkecimpung dalam mempelajari ilmu mempertahankan diri, pengkaji sentiasa mencari keistimewaan dan simbolik yang terdapat dalam seni silat. Misalnya, semasa memenuhi kehendak subjek projek akhir tahun pelajar pada tahun 2015, pengkaji telah melakukan kajian ke atas adat-istiadat dalam seni silat. Dalam kajian pada kali ini pula, pengkaji telah berjaya merungkai proses rawatan tradisional yang digunakan oleh pengamal perubatan untuk merawat pelatih. Hal ini demikian kerana, pengamal perubatan yang memberikan rawatan kepada pelatih adalah terdiri daripada para gurulatih itu sendiri. Ini membuktikan bahawa gurulatih sememangnya mempunyai kemahiran dan kepakaran yang lebih daripada sekadar mengajar ilmu persilatan tetapi juga mempunyai ilmu pengubatan.

\subsection{Limitasi}

Sepanjang proses kajian dijalankan, kesemua soalan yang diajukan kepada informan adalah sama sahaja dan yang berbeza hanyalah pendapat. Melalui pendapat dan pengalaman informan tersebut hanya segelintir sahaja daripada pelatih yang tidak dapat meneruskan rawatan melalui kaedah perubatan tradisional. Jika ditanya perihal mengapakah tidak dapat dirawat melalui perubatan tradisional? Jawapan yang diterima dari informan yang terdiri daripada gurulatih dan perawat daripada pusat rawatan Islam memberitahu bahawa kesemua pesakit perlu merujuk kepada hospital dan klinik terlebih dahulu. Hal ini demikian bagi mengetahui dengan lebih jelas punca berlakunya penyakit dan memberikan rawatan yang sewajarnya. Di samping itu, jika pihak hospital tidak mampu untuk memberi rawatan barulah pesakit bebas untuk memilih kaedah perubatan tradisional.

Kesemua informan yang telah ditemubual menyatakan bahawa mereka hanya berikhtiar dengan menggunakan kepakaran yang ada untuk menyembuhkan setiap penyakit yang dihadapi oleh pesakit. Menurut pengamal perubatan lagi, dalam kes mengubati penyakit fizikal, mereka hanya boleh merawat penyakit seperti luka-luka kecil dan kecederaan yang kecil sahaja. Jika kecederaan tersebut dikhuatiri sukar untuk sembuh, para pengamal perubatan akan merujuk pesakit tersebut ke hospital untuk menerima rawatan yang lebih 
dijamin selamat

Manakala bagi urusan penyembuhan penyakit spiritual untuk masyarakat yang beragama Islam pula kebanyakan pesakit akan sembuh dengan izin Allah namun pesakit tetap memerlukan kesabaran yang tinggi untuk kembali sembuh. Tambahan pula, pesakit juga haruslah melengkapkan diri dengan ilmu agama yang cukup kuat untuk dijadikan pembenteng daripada ditipu makhluk halus. Pengamal juga memberitahu bahawa setiap penyakit yang dihadapi merupakan tanda ujian dari Allah Yang Maha Kuasa dan pesakit haruslah percaya dengan Qada' dan Qadar yang telah ditetapkan olehNya.

Menerusi penulisan ini, pengkaji lebih menekankan suasana pengubatan tradisional yang berlaku di antara pengamal perubatan dengan pelatih seni silat sahaja. Jika diluar daripada gelanggang seni silat, jurulatih atau pengamal perubatan sememangnya memberikan khidmat rawatan kepada masyarakat yang mempunyai penyakit. Misalnya, Cikgu Zain dan Pak Kamal amat mengalu-alukan masyarakat yang mempunyai penyakit untuk berkunjung ke kediaman beliau bagi mendapatkan rawatan. Selain itu, Ustaz Zaki juga merupakan penaung Pusat Perubatan Islam Darussyifa' yang juga menawarkan khidmat rawatan kepada semua pesakit.

\subsection{Kesimpulan}

Secara keseluruhannya, pengkaji telah membincangkan kajian mengikut beberapa urutan. Untuk permulaan kajian, pengkaji telah menceritakan secara lebih jelas mengenai sejarah Seni Silat di Malaysia dan khususnya di Kelantan. Seterusnya, kajian lebih bertumpu kepada jenis penyakit serta kaedah perubatan tradisional yang sering digunakan oleh pengamal perubatan. Lebih mengagumkan lagi, semasa menemubual beberapa orang gurulatih mendapati mereka bukan sahaja bertanggungjawab dalam mengajar ilmu seni bela diri malah juga bertindak sebagai pengamal perubatan. Gurulatih juga biasanya akan merawat para pelatih yang mengalami penyakit fizikal dan spiritual menggunakan kemahiran yang dimiliki dan merawat menerusi beberapa kaedah tradisional yang bersesuaian dengan penyakit. Menerusi pemerhatian yang telah dilakukan, terdapat dua jenis penyakit utama yang seringkali menyerang pelatih iaitu penyakit fizikal dan penyakit spiritual. Di pertengahan kajian pula pengkaji lebih menekankan perihal proses atau cara mengubati penyakit fizikal dan spiritual. Di akhir sekali, pengkaji telah melakukan analisis terhadap keseluruhan kajian dan mendapati bahawa setiap penyakit yang dirawat melalui kaedah tradisional juga memberikan kesan yang memberangsangkan.

\section{Rujukan}

Aisyah@ Eshah Haji Mohamed dan Abd Aziz Bidin (2012). Tumbuhan Dalam UpacaraPerbomohan: Kes Main Teri di Kelantan. Journal of Society and Space 8 issue 4 ms. 56-63.

Amran Hassan, Fatimah Yusoof dan Khadijah Alavi (2012). Keluarga Sihat Melahirkan KomunitiSejahtera: Satu Ulasan. Pusat Pengajian Psikologi dan Pembangunan Manusia, Fakulti Sains Sosial dan Kemanusiaan, Universiti Kebangsaan Malaysia.

Azlina Musa dan Yusmilayati Yunos (2011). Simptom-simptom penyakit Dalam Main Teri: satukajian kes di Kampung Pasir Mas, Kelantan. Jurnal Melayu (8), ms. 233-249 
Faisal@Ahmad Faisal Abdul Hamid dan Nurul Wahidah Fauzi, (2012). Perubatan MelayuTradisional: Kitab Tibb Pontianak. Jurnal Al-Tamaddun Bil. 7(1), ms. 142-162.

H.C Ong (1994). "Malay Herbal Medicine in Gemencheh, Negeri Sembilan, Malaysia",Fitoterapia, vol 1, issue 1, Feb 1994, ms. 10-14

Haron Daud dan Abdul Rahman Hj Ismail (Editor), (2014). Hang Tuah wira bangsa. Penerbit Universiti Malaysia Kelantan.

Haron Din (2011) a. Siri Pengajian Perubatan Islam. Rawatan penyakit rohani: hafalan ruqyah asas ketiga, gangguan emosi dan makhluk halus. Jilid 4. Persatuan Kebajikan dan Pengubatan Islam Malaysia dan Koperasi Darussyifa' Berhad.

Haron Din (2011) b. Siri Pengajian Perubatan Islam. Rawatan Penyakit Akibat Sihir: kaedah mengelak, menentang dan mengatasi sihir. Jilid 5. Persatuan Kebajikan dan Pengubatan Islam Malaysiadan Koperasi Darussyifa' Berhad.

Ibrahim Jantan (2006). "The Scientific Values of Malaysian Herbal Products", Jurnal Sains Kesihatan Malaysia, Vol 4, Jilid 1, ms. 59-70

Intan Farhana Saparudin et, al. (2014). Pemahaman konsep histeria dalam masyarakat Melayu. Seminar Antarabangsa Dakwah dan Etnik; dakwah dan Etnik: Perspektif Multi-disiplin. Pusat Kajian Dakwah Orang Asli dan Pribumi, UKM, Bangi, Selangor.

Kamus Dewan Edisi Keempat (2010). Dewan Bahasa dan Pustaka. Kuala Lumpur. Ms. 58(angin), ms. 389 (emosi), ms. 1433 (semangat), halaman 1490 (sihir).

Khairul Ghazali (2014). Fadhilat dan Keutamaan Ayat Qursi. Pustaka Azhar, Johor Bharu.

Nisriwani Yahaya, Syed Zulflida S.M. Noor (penulis) (2003). 101 Puteri dunia Melayu, sejarah dan lagenda. Penasihat: Dato' Dr Adi Hj Taha. Jabatan Muzium dan Antikuiti.

Nurdeng Deuraseh dan Hayati Lateh, (2011). Rukyah (Jampi) Dalam Perubatan Tradisional Melayu Sebagai Rawatan Penyakit, Pencegahan, Pendinding Diri dan Harta: Kehebatan dan Sumbangan Ilmuwan Nusantara. Prosiding Nadwah Ulama Nusantara (NUN). Jabatan Pengajian Arab dan Tamadunlslam, Fakulti Pengajian Islam, Universiti Kebangsaan Malaysia, Bangi, Selangor.

Mat Saad Abd Rahman (2008). Isu-isu dalam Masyarakat Islam Malaysia. iBook Publication Sdn. Bhd, Rawang.

Mohd Hilmi Abdullah (2014). Khasiat Tumbuh-tumbuhan Menurut Ibnu Sina. Pustaka Hilmi, Kuala Kubu Bharu, Selangor.

Mohd Qayyuum bin Kamarudin et, al. (2020). Tasawur Perubatan Melayu Berdasarkan Kitab Perubatan Melayu. International Journal of Islamic and Civilizational Studies. Vol 6, no.3-2.

Muhammad Faiz Mohd Nazri (2018). Fungsi Ruqyah Syar'iyyah dalam Mengobati Penyakit Non Medis. Fakultas Dakwah dan Komunikasi, Universiti islam Negeri Ar-Raniry Darussalam, 
Banda Acheh.

Muhammad Takari Jilin Syahrial (2015). Adat dalam peradaban Melayu. Laporan penelitian. Program Studi Etnomusikologi FIB USU dan Majlis Adat Budaya Melayu Indonesia.

Phayilah Yama, Ikmal Zaidi Hashim, dan Farhah Zaidar Mohamed Ramli (2017). Kaedah dan Faktor Keberkesanan Perubatan Islam Ruqyah: Kajian Kes Dr. Jahid Sidek. Kolej Universiti Islam Selangor, KUIS.

Rahimidin Zahari dan Sutung Umar RS (2011). Makyung warisan mistik Malaysia. Institut Terjemahan Negara Malaysia, Kuala lumpur.

Ramli Abdul Ghani (2011). Garis Panduan Pengubatan Islam. Bahagian Perubatan Tradisional dan Komplimentari, Cawangan Amalan dan Pendaftaran, Kuala Lumpur.

Rosnani Ripin, (2016). Amalan Urut Melayu Tradisional Patuh Syariah. Muzakarah Fiqh dan International Fiqh Conference. Kolej Islam Antarabangsa Sultan ismail Petra (KIAS).

Ruzita Alias, (Editor), (2011). Citra Seni. Perpustakaan Negara Malaysia, KementerianPenerangan Komunikasi dan Kebudayaan.

Sheikh Shamsuddin (2005). The Malay art of self-defense. Silat Seni Gayong. North Atlantic Books. Berkeley, California.

Supyan Hussin (2017). Seni Silat Melayu satu perlambangan akal budi Melayu. Wacana Warisan Borneo. Anjuran Bersama Unit Penyelidikan Warisan Borneo, Universiti Malaysia Sabah, Majlis Profesor Negara dan ATMA-UKM.

Muhammad Takari Jilin Syahrial, (2015). Adat Dalam Peradaban Melayu. Program Studi Etnomusikologi FIB USU dan Majlis Adat Budaya Melayu Indonesia. 